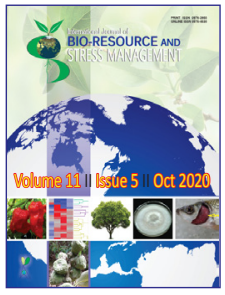

\title{
Effect of Biochar on Yield and Quality of Potato (Solanum tuberosum) Tuber
}

\author{
Md. Omar Ali Mollick ${ }^{1 *}$, Alok Kumar Paul ${ }^{1}$, Ishrat Alam¹, Munshi Mohammad Sumon²
}

${ }^{1}$ Dept. of Soil Science, ${ }^{2}$ Dept. of Biochemistry, Sher-e-Bangla Agricultural University, Dhaka (12 07), Bangladesh

Open Access

Corresponding Author

Md. Omar Ali Mollick

e-mail: omarali@sau.edu.bd

Citation: Mollick et al., 2020. Effect of Biochar on Yield and Quality of Potato (Solanum tuberosum) Tuber. International Journal of Bio-resource and Stress Management 2020, 11(5), 445-450. HTTPS://DOI. ORG/10.23910/1.2020.2140.

Copyright: () 2020 Mollick et al. This is an open access article that permits unrestricted use, distribution and reproduction in any medium after the author(s) and source are credited.

Data Availability Statement: Legal restrictions are imposed on the public sharing of raw data. However, authors have full right to transfer or share the data in raw form upon request subject to either meeting the conditions of the original consents and the original research study. Further, access of data needs to meet whether the user complies with the ethical and legal obligations as data controllers to allow for secondary use of the data outside of the original study.

Funding: The funds for this research work are provided by Ministry of Science and Technology, The Peoples Republic of Bangladesh

Conflict of interests: The authors have declared that no conflict of interest exists.

\begin{abstract}
A field experiment was conducted in Sher-e-Bangla Agricultural University (SAU), Dhaka, Bangladesh during the period from November, 2017 to March, 2018 in rabi season to observe the effect of biochar on the yield and quality of potato tuber and to find out the optimum dose of biochar along with inorganic fertilizer for achieving the maximum yield of potato. The experiment consist of 9 treatments as Control (no chemical fertilizer and biochar), Recommended Fertilizer Dose; Recommended Fertilizer Dose+Biochar @ 2.5 t ha $^{-1}$; Recommended Fertilizer Dose+Biochar @ 5.0 t ha-1; Recommended Fertilizer Dose+Biochar @ 7.5 t ha-1; $1 / 2$ of Recommended Fertilizer Dose+Biochar @ $2.5 \mathrm{t} \mathrm{ha}^{-1}$; 1/2 of Recommended Fertilizer Dose+Biochar @ 5.0 t ha $^{-1} ; 1 \frac{1}{2}$ of Recommended Fertilizer Dose + Biochar @ $7.5 \mathrm{t} \mathrm{ha}^{-1}$; Biochar @ $10 \mathrm{t} \mathrm{ha}^{-1}$. The experiment was laid out in a Randomized Complete Block Design with three replications. The tested variety was BARI Alu-7 (Diamant). Data were collected on different yield attributes, growth and quality of potato and postharvest soil analysis. The results indicated that biochar application significantly $(p<0.05)$ increased plant height, weight of tubers, yield of tubers, tuber dry matter content, tuber specific gravity, soil organic carbon. Results suggested that biochar application had significant positive effect on plant and soil.
\end{abstract}

Keywords: Biochar, growth, yield, potato tuber

\section{Introduction}

Increasing human pressure on agricultural fields and pastures while depleting land currently under agricultural use further increasing climate change and so on (Lal, 2009). Therefore, sustainable concepts for increased food production are now needed to lower the pressure on our soil. In this regard it is the need to preserve and replenish soil organic matter reserves to sustain nutrient cycling, aid water use efficiency and help mitigate against climate change. Under this situation, the use of biochar (BC) can be an effective means for sustainable agriculture in the long term, increasing soil $C$ sequestration ( $C$ reduction strategy), fertility and productivity (soil quality) and reducing greenhouse gas emissions (Jeffery et al., 2014).

Soil organic carbon (SOC) is a basic factor in soil fertility and plays a significant role in the global carbon cycle (Liang et al., 2019). Biochar can increase SOC via either the release of biochar-derived dissolved organic matter or by preserving the existing natural SOC (Al-Wabel et al., 2017; Aller et al., 2017). Biochar's positive role in increasing crop yields is often credited to its porosity and sorption capacity (Gul et al., 2015); its liming effects in acidic soils (Peng et al., 2011); its enhancement of soil water holding capacity, pore-size distribution, and soil structure
Article History

RECEIVED in $25^{\text {th }}$ July 2020
RECEIVED in revised form $05^{\text {th }}$ October 2020

ACCEPTED in final form $18^{\text {th }}$ October 2020 
stability (Chan et al., 2007; Jhou et al., 2019 ); its high rate of nutrient transformations and utilization efficiency (Mizuta et al., 2004); and its stimulation of microbial and enzymatic activity (Bhattacharjya et al., 2016).

Biochar is the solid, carbon-rich material obtained by pyrolysis using different biomasses under low or no oxygen conditions (Brassard et al., 2016). It has been documented in some previous studies that biochar improves crop growth and yield (Rawat et al., 2019), increases nutrient availability in the soil and plant root colonization by mycorrhizal fungi (Koide, 2017), reduces emissions of other greenhouse gases from soil (Van Zwieten et al., 2015) and increases soil CEC, which improves plant nutrient availability and is thus beneficial for plant growth (Atkinson et al., 2010).

Treating plants with biochar increased plant growth, yield and quality (Gupta et al., 2020, Silva et al., 2017, Bonanomi et al., 2017, Dou et al., 2012, Carter et al., 2013, Vaccari et al., 2015, Akhtar et al., 2014). Also, biochar addition to mineral fertilizers significantly increased plant growth (Schulz and Glaser, 2012, Biederman and Harpole, 2013). Graber et al. (2010) mentioned that treating tomato plants by biochar positively enhanced plant height and leaf size. Nair (2015), on potato cv. Atlantic, found that there was a general trend of increasing yields with increasing biochar application rates. Adding biochar to the field of potato plants improved plant growth, tuber yield and its components with good tubers quality (Youseef et al., 2017, El-Metwaly, 2020).

Potato (Solanum tuberosum L.) is one of the most widely cultivated vegetable crops with a world production of about 368 million tons per year. In the world, it is the 4th crop after wheat, rice and maize (FAOSTAT, 2019). Potato has excellent food qualities such as water, carbohydrates, starch, proteins and contains negligible fat. In the present study, Potato (Solanum tuberosum) was grown under different treatments (biochar and mineral fertilization) in a field experiment. The objectives of this study were: (1) to observe the effect of biochar on yield and yield contributing factors of potato (2) to study the efficacy of biochar on quality of potato tuber (3) to find out the optimum dose of biochar along with inorganic fertilizer for achieving the maximum yield of potato.

\section{Materials and Methods}

\subsection{Description of the study area}

The study was conducted in the farm of Sher-e-Bangla Agricultural University, Sher-e-Bangla Nagar, Dhaka-1207. Bangladesh in the year 2017. It is located at $23^{\circ} 74^{\prime} \mathrm{N}$ latitude and $90^{\circ} 33^{\prime} \mathrm{E}$ longitude at an altitude of 8.6 meter above the sea level. The mean annual maximum and minimum temperatures are $26.8^{\circ} \mathrm{C}$ and $11.4^{\circ} \mathrm{C}$ and the relative humidity's are $91.4 \%$ and $39.92 \%$, respectively. The mean annual rainfall of the study area is $1500 \mathrm{~mm}$.

\subsection{Treatments details of experimental fields}

The experiment consist of 9 treatments as $T_{1}=$ Control (no chemical fertilizer and biochar), $T_{2}=R F D$ (Recommended
Fertilizer Dose); $\mathrm{T}_{3}=\mathrm{RFD}+$ Biochar @ 2.5 ton $^{-1} \mathrm{~h}^{-1} ; \mathrm{T}_{4}=\mathrm{RFD}+$ Biochar @ 5.0 t ha $^{-1} ; \mathrm{T}_{5}=\mathrm{RFD}+$ Biochar @ $7.5 \mathrm{t} \mathrm{ha}^{-1} ; \mathrm{T}_{6}={ }^{1} / 2$ of RFD+Biochar @ $2.5 \mathrm{t} \mathrm{ha}^{-1} ; \mathrm{T}_{7}=1 / 2$ of RFD+Biochar @ $5.0 \mathrm{tha}^{-1} ; \mathrm{T}_{8}=1 / 2$ of RFD+Biochar@ $7.5 \mathrm{t} \mathrm{ha}^{-1} ; \mathrm{T}_{9}=$ Biochar @ $10 \mathrm{t} \mathrm{ha}^{-1}$. RFD (Recommended Fertilizer Dose): for potato $\mathrm{N}_{150}, \mathrm{P}_{30}, \mathrm{~K}_{140^{\prime}}, \mathrm{S}_{15^{\prime}}$, $\mathrm{Zn}_{3} \mathrm{~kg} \mathrm{ha}^{-1}$ (FRG, 2012).

\subsection{Experimental procedure}

The experiment was laid out in Randomized Complete Block Design (RCBD) with three replications. The entire amount of biochar (as per treatment), triple super phosphate, gypsum, zinc sulphate and half of urea and full of MoP were applied as basal dose at two days before potato planting. The well sprouted healthy and uniform sized potato tubers were planted maintaining a spacing $40 \times 20 \mathrm{~cm}^{2}$ and $4-5 \mathrm{~cm}$ depth. Normal growth conditions were ensured and the field was irrigated to maintain the soil moisture in field capacity.

\subsection{Harvesting of potatoes and collecting of data}

Plant height, number of stems hill ${ }^{-1}$ and tubers hill-1 were counted at harvest. Harvested potato tubers were separated into marketable (fresh weight $>20 \mathrm{~g}$ ), non-marketable tubers (fresh weight $<20 \mathrm{~g}$ ) as per treatment and yield was calculated tonha-1. The tuber sub samples were collected from each treatment. After peel off the tubers the samples were dried in oven at $72^{\circ} \mathrm{C}$ for 72 hours. From which the weights of tuber flesh dry matter content \% were recorded. From which the dry matter percentage of tuber was calculated with the following formula: Dry matter content (\%) $=$ (Dry weight $\div$ Fresh weight) $\times 100$ (Elfresh et al., 2011). The specific gravity was measured for one sample per treatment. Tubers were randomly taken from each plot and washed with water, following which they were first weighed in air and then in water. The specific gravity of the tubers was then calculated using the following equation (Mohammed, 2016): Specific gravity=(weight in air)/(weight in air- weight in water)

\subsection{Soil analysis}

Soil samples were analyzed at the beginning of experiment and after the harvest of potato to determine soil $\mathrm{pH}$, organic carbon, total nitrogen $(\mathrm{N})$, available phosphoprus $(\mathrm{P})$, exchangeable potassium (K), available sulphur (S). Soil $\mathrm{pH}$ was measured by using a $\mathrm{pH}$ meter in a 1:2.5 soil water ratio, organic carbon in soil sample was determined by wet oxidation method (Page et al., 1982). Kjeldahl method was used to determine the total $\mathrm{N}$ content of soil. Available P was determined by ascorbic acid blue color method. (Olsen et al., 1984). Exchangeable $\mathrm{K}$ was determined by $1 \mathrm{~N} \mathrm{NH}_{4} \mathrm{OAc}(\mathrm{pH}=7)$ extraction methods, available Sulphur was determined by $\mathrm{CaCl}_{2}$ extraction method (Page et al., 1982) (Table 1).

\subsection{Statistical analysis}

The data obtained for different parameters were statistically analyzed by using statistix 10 software to find out the significant $(p<0.05)$ difference among the results of different levels of biochar application on growth, yield and yield contributing 


\begin{tabular}{|c|c|c|c|}
\hline Physical properties & Value & Chemical properties & Value \\
\hline $\begin{array}{l}\text { Mechanical } \\
\text { fractions: }\end{array}$ & & $\mathrm{pH}$ & 5.9 \\
\hline $\begin{array}{l}\text { \% Sand }(2.0-0.02 \\
\mathrm{mm})\end{array}$ & 27 & Organic carbon (\%) & 0.72 \\
\hline $\begin{array}{l}\text { \% Silt (0.02-0.002 } \\
\mathrm{mm})\end{array}$ & 43 & Total N (\%) & 0.06 \\
\hline $\begin{array}{l}\% \text { Clay }(<0.002 \\
\mathrm{mm})\end{array}$ & 30 & Available P (ppm) & 16.27 \\
\hline \multirow[t]{2}{*}{ Textural class } & $\begin{array}{l}\text { Clay } \\
\text { loam }\end{array}$ & $\begin{array}{l}\text { Exchangeable } \mathrm{K} \text { (me } \\
100 \mathrm{~g}^{-1} \text { soil) }\end{array}$ & 0.12 \\
\hline & & Available S (ppm) & 16.5 \\
\hline
\end{tabular}

characters of potato. The mean values of all the characters were calculated and analysis of variance was performed. The significance of the difference among the treatment means was estimated by Least Significant Difference test at $5 \%$ level of probability (Gomez and Gomez, 1984).

\section{Results and Discussion}

\subsection{Effect of biochar on plant growth}

Plant height was significantly $(p<0.05)$ influenced due to application of different levels of biochar (Table 2). The maximum plant height $63.23 \mathrm{~cm}$ at harvesting which was recorded from $T_{5}$ treatment whereas, the minimum plant height was recorded from control treatment. Plant height was significantly $(p<0.05)$ increased due to application of biochar. Graber et al. (2010) emphasized that treating plants by biochar positively enhanced plant height. Biochar addition to mineral fertilizers significantly increased plant growth (Schulz and Glaser, 2012). Therefore, the combination of biochar with organic fertilizer (compost) is most promising for agronomic performance.

The number of stems per hill at haulm cutting stage significantly $(p<0.05)$ increased only over control (Table 2$)$. The maximum stem numbers hill ${ }^{-1}$ (5.17) was obtained from $\mathrm{T}_{6}$ treatment which was statistically not significant $(p<0.05)$ with other treatments. Youseef et al. (2017) revealed that the number of main stems significantly increased with increasing biochar application rates up to $12 \mathrm{~m}^{3} \mathrm{ha}^{-1}$.

\subsubsection{Effect of biochar on yield attributes potato yield}

We found the number of tubers hill ${ }^{-1}$ increased significantly due to different rate of biochar application (Table 2). The maximum number of tubers hill ${ }^{-1}$ was produced from $1 / 2$ of RFD+Biochar@ $2.5 \mathrm{t} \mathrm{ha}^{-1}$ treatment whereas the minimum was produced from control treatment. Youseef et al. (2017) found that fertilizing with biochar positively increased number of tubers. The tuber yield of potato increased significantly $(p<0.05)$ due to application of biochar in combination with chemical fertilizers (Table 2). The highest tuber yield (35.76 $\mathrm{t} \mathrm{ha}^{-1}$ ) was obtained from $\mathrm{T}_{5}$ (RFD+Biochar @ $7.5 \mathrm{t} \mathrm{ha}^{-1}$ ) treatment lowest tuber yield $\left(14.51 \mathrm{tha}^{-1}\right)$ was obtained from $\mathrm{T}_{1}$ (control) treatment.

Numerous studies have indicated the strong potential of biochar application for improving crop yields (Van Zwieten et al., 2010; Zhang et al., 2012; Nair et al., 2014). A number of other studies have shown only small improvements or even reductions in grain yield with biochar application in nutrient-rich soils (Deenik et al., 2010; Gaskin et al., 2010; Van Zwieten et al., 2010). For instance, Gaskin et al. (2010) noted a decrease in grain yield with increasing rates of biochar application. Increased crop yield is a mostly recognized benefit of biochar application; however, crop responses are highly variable and reliant on biochar type and application rates.

\subsubsection{Effect of biochar on quality of potato}

Dry matter content (\%) of tubers increased significantly $(p<0.05)$ by different levels of biochar application. Youseef et al. (2017) found that the total dry weight of tubers significantly increased (15.60\%) with increasing of biochar application rate. Specific Gravity Specific gravity of tuber increased significantly $(p<0.05)$ with different levels of biochar application (Table 2). The highest specific gravity (1.12) of tuber was recorded from $\mathrm{T}_{5}$ (RFD+Biochar @ 7.5 $t \mathrm{ha}^{-1}$ ) treatment and the lowest was found from $T_{1}$ (1.03) treatment. Based on weight, tubers have been graded into marketable tuber (>20 g) and non-marketable tuber $(<20 \mathrm{~g})$. The results indicate that there was significant difference in the treatments in respect of production of different grades of tubers. The highest percentage (31.86\%) of non-marketable tuber $(<20 \mathrm{~g})$ was produced from control treatment and the lowest percentage $(23.55 \%)$ of non-marketable tuber $(<20 \mathrm{~g})$ was produced from $\mathrm{T}_{5}$ treatment. The maximum percentage $(76.45 \%)$ of marketable tuber (>20 g) was produced from $T_{5}$ (RFD+Biochar@ $0.5 \mathrm{t} \mathrm{ha}^{-1}$ ) treatment while the minimum percentage (68.14\%) of marketable tuber was produced from $\mathrm{T}_{1}$ treatment.

\subsection{Effect of biochar on postharvest soil properties}

We found no significant $(p<0.05)$ difference in soil $\mathrm{pH}$ between treatments. (Table 3). Wang et al. (2014) found that rice husk biochar increased the tea garden soil (acid soil) pH from 3.33 to 3.63 . The agricultural soil $\mathrm{pH}$ increased by almost $1 \mathrm{pH}$ unit for biochar treatment which produced from mixed hardwood (Quercus spp. and Carya spp.) (Laird et al. 2010).

Soil organic carbon found due to biochar application from different treatment was statistically significant. The highest organic carbon $(0.84 \%)$ was recorded in $\mathrm{T}_{4}$ (RFD+Biochar @ $5.0 \mathrm{t} \mathrm{ha}^{-1}$ ) treatment which was statistically similar with $\mathrm{T}_{3}(0.82 \%), \mathrm{T}_{5}(0.82 \%), \mathrm{T}_{6}(0.84 \%), \mathrm{T}_{7}(0.84 \%), \mathrm{T}_{8}(0.83 \%), \mathrm{T}_{9}$ $(0.84 \%)$ treatments, while the lowest organic carbon $(0.77 \%)$ was recorded from $\mathrm{T}_{1}$ treatment (Table 3 ). Increase in organic C (up to $69 \%$ ) due to biochar application was found by Laird et al., 2010. 


\begin{tabular}{|c|c|c|c|c|c|c|c|c|c|}
\hline Treatment & $\begin{array}{c}\text { Plant } \\
\text { height } \\
(\mathrm{cm})\end{array}$ & $\begin{array}{c}\text { No. of } \\
\text { stem hill-1 }\end{array}$ & $\begin{array}{c}\text { No. of } \\
\text { tubers } \\
\text { hill-1 }^{-1}\end{array}$ & $\begin{array}{l}\text { Weight } \\
\text { of tubers } \\
\left(\mathrm{kg} \mathrm{hill}^{-1}\right)\end{array}$ & $\begin{array}{c}\text { Yield of } \\
\text { tuber } \\
\text { t ha-1 }^{-1}\end{array}$ & $\begin{array}{l}\text { Tuber dry } \\
\text { matter } \\
\text { content } \\
(\%)\end{array}$ & $\begin{array}{c}\text { Tuber } \\
\text { specific } \\
\text { gravity }\end{array}$ & $\begin{array}{l}\text { Weight of } \\
\text { marketable } \\
\text { yield >20 g } \\
(\%)\end{array}$ & $\begin{array}{c}\text { Weight of non } \\
\text {-marketable } \\
\text { yield }<20 \mathrm{~g} \\
(\%)\end{array}$ \\
\hline $\mathrm{T}_{1}$ & $40.23^{h}$ & $4.00^{c}$ & $5.52^{c}$ & $0.11^{d}$ & $14.51^{\mathrm{e}}$ & $15.00^{e}$ & $1.03^{f}$ & $68.14^{b}$ & $31.86^{a}$ \\
\hline $\mathrm{T}_{2}$ & $55.73^{d}$ & $4.27^{b c}$ & $7.27^{a b}$ & $0.41^{\mathrm{abc}}$ & $25.96^{\mathrm{bcd}}$ & $18.00^{\text {cd }}$ & $1.06^{\text {cde }}$ & $73.62^{\mathrm{ab}}$ & $26.38^{\mathrm{ab}}$ \\
\hline $\mathrm{T}_{3}$ & $61.26^{b}$ & $4.70^{\mathrm{abc}}$ & $7.62^{\mathrm{ab}}$ & $0.50^{\mathrm{a}}$ & $31.56^{\mathrm{abc}}$ & $20.33^{b c}$ & $1.07^{c}$ & $73.25^{\mathrm{ab}}$ & $26.75^{\mathrm{ab}}$ \\
\hline $\mathrm{T}_{4}$ & $58.45^{c}$ & $5.10^{a}$ & $7.60^{\mathrm{ab}}$ & $0.49^{a b}$ & $33.56^{\mathrm{ab}}$ & $22.67^{\mathrm{ab}}$ & $1.10^{b}$ & $74.04^{\mathrm{ab}}$ & $25.96^{\mathrm{ab}}$ \\
\hline $\mathrm{T}_{5}$ & $63.23^{a}$ & $4.37^{a b c}$ & $8.00^{a}$ & $0.51^{a}$ & $35.76^{a}$ & $25.33^{a}$ & $1.12^{\mathrm{a}}$ & $76.45^{a}$ & $23.55^{b}$ \\
\hline $\mathrm{T}_{6}$ & $54.28^{e}$ & $5.17^{a}$ & $8.37^{a}$ & $0.34^{\mathrm{abc}}$ & $25.94^{\mathrm{bcd}}$ & $23.33^{a}$ & $1.07^{c d}$ & $75.22^{\mathrm{a}}$ & $24.79^{b}$ \\
\hline $\mathrm{T}_{7}$ & $53.59^{e}$ & $4.83^{a b}$ & $6.67^{b c}$ & $0.34^{b c}$ & $25.10^{\mathrm{cd}}$ & $20.33^{b c}$ & $1.05^{\mathrm{ef}}$ & $75.59^{a}$ & $24.41^{b}$ \\
\hline $\mathrm{T}_{8}$ & $47.75^{f}$ & $4.43^{\mathrm{abc}}$ & $6.63^{b c}$ & $0.41^{\mathrm{abc}}$ & $24.14^{\mathrm{cd}}$ & $16.67^{\text {de }}$ & $1.06^{\text {cde }}$ & $74.30^{\mathrm{ab}}$ & $25.70^{\mathrm{ab}}$ \\
\hline $\mathrm{T}_{9}$ & $45.55^{\mathrm{g}}$ & $4.77^{a b c}$ & $5.67^{c}$ & $0.30^{c}$ & $19.78^{\text {de }}$ & $16.33^{\text {de }}$ & $1.05^{\mathrm{de}}$ & $74.74^{a}$ & $25.56^{b}$ \\
\hline $\begin{array}{l}\text { LSD } \\
(p=0.05)\end{array}$ & 1.24 & 0.82 & 3.39 & 0.17 & 1.75 & 2.74 & 0.02 & 6.18 & 6.18 \\
\hline
\end{tabular}

In a column means having similar letter (s) are statistically similar and those having dissimilar letter (s) differ significantly by LSD $(p=0.05)$ level of probability

Biochar application significantly $(p<0.05)$ influenced the total nitrogen (\%) content of soil. The maximum total nitrogen $(0.089 \%)$ was recorded in $\mathrm{T}_{5}$ (RFD+Biochar @ $7.5 \mathrm{t} \mathrm{ha}^{-1}$ ) treatment and minimum was recorded from control treatment (Table 3). We found that biochar application increased the total nitrogen (\%) content of soil. Such an effect could be interpreted as CEC was increased due to the presence of cation exchange sites on the biochar surface (Lehmann, 2007; Sohi et al., 2010). This contributed to retain higher $\mathrm{NH}_{4}{ }^{+}$concentrations leading to improved $\mathrm{N}$ nutrition in the biochar-amended soil (Hollister et al., 2013). Liard et al. (2010) found that the biochar amendments significantly increased total N (up to 7\%).

The different treatment showed significantly variation in the Available phosphorus. The highest available phosphorus (28.7 ppm) was recorded from $T_{4}$ while the lowest available phosphorus (17.5 ppm) was recorded from $\mathrm{T}_{1}$ treatment (Table 3). Xu et al. (2014) showed that biochar affect $P$ availability by interaction with other organic and inorganic components in the soil, including organic matter or other base cations in the soil.

Exchangeable potassium was significantly influenced by different treatment. The highest exchangeable potassium

\begin{tabular}{lcccccc}
\hline \multicolumn{6}{l}{ Table 3: Effect of biochar on of postharvest soil properties } \\
\hline Treatment & Soil pH & $\begin{array}{c}\text { Organic carbon } \\
(\%)\end{array}$ & $\begin{array}{c}\text { Total N } \\
(\%)\end{array}$ & $\begin{array}{c}\text { Available } \mathrm{P} \\
(\mathrm{ppm})\end{array}$ & $\begin{array}{c}\text { Exchangeable K } \\
\left(\mathrm{cmol} \mathrm{kg}^{-1} \text { soil) }\right.\end{array}$ & $\begin{array}{c}\text { Available S } \\
(\mathrm{ppm})\end{array}$ \\
\hline $\mathrm{T}_{1}$ & 6.0 & $0.70^{\mathrm{f}}$ & $0.05^{\mathrm{i}}$ & $17.5^{\mathrm{d}}$ & $0.15^{\mathrm{f}}$ & $16.50^{\mathrm{c}}$ \\
$\mathrm{T}_{2}$ & 6.10 & $0.76^{\mathrm{e}}$ & $0.063^{\mathrm{h}}$ & $21.8^{\mathrm{c}}$ & $0.18^{\mathrm{d}}$ & $21.50^{\mathrm{c}}$ \\
$\mathrm{T}_{3}$ & 6.12 & $0.79^{\mathrm{de}}$ & $0.081^{\mathrm{c}}$ & $23.2^{\mathrm{bc}}$ & $0.19^{\mathrm{c}}$ & $22.50^{\mathrm{c}}$ \\
$\mathrm{T}_{4}$ & 6.13 & $0.82^{\mathrm{cd}}$ & $0.087^{\mathrm{b}}$ & $28.7^{\mathrm{a}}$ & $0.20^{\mathrm{c}}$ & $22.50^{\mathrm{c}}$ \\
$\mathrm{T}_{5}$ & 6.15 & $0.88^{\mathrm{b}}$ & $0.089^{\mathrm{a}}$ & $27.3^{\mathrm{a}}$ & $0.24^{\mathrm{a}}$ & $26.66^{\mathrm{a}}$ \\
$\mathrm{T}_{6}$ & 6.20 & $0.84^{\mathrm{c}}$ & $0.072^{\mathrm{g}}$ & $27.0^{\mathrm{a}}$ & $0.22^{\mathrm{b}}$ & $25.00^{\mathrm{b}}$ \\
$\mathrm{T}_{7}$ & 6.10 & $0.86^{\mathrm{bc}}$ & $0.075^{\mathrm{f}}$ & $22.5^{\mathrm{c}}$ & $0.20^{\mathrm{c}}$ & $22.00^{\mathrm{c}}$ \\
$\mathrm{T}_{8}$ & 6.11 & $0.88^{\mathrm{b}}$ & $0.078^{\mathrm{e}}$ & $24.3^{\mathrm{bc}}$ & $0.19^{\mathrm{c}}$ & $22.20^{\mathrm{c}}$ \\
$\mathrm{T}_{9}$ & 6.12 & $0.98^{\mathrm{a}}$ & $0.079^{\mathrm{d}}$ & $26.3^{\mathrm{ab}}$ & $0.16^{\mathrm{e}}$ & $19.97^{\mathrm{d}}$ \\
LSD $(p=0.05)$ & $\mathrm{NS}$ & 0.05 & 0.04 & 0.66 & 0.02 & 0.88 \\
\hline
\end{tabular}

In a column means having similar letter (s) are statistically similar and those having dissimilar letter (s) differ significantly by LSD $(p=0.05)$ level of probability 
(0.24 $\mathrm{cmol} \mathrm{kg}^{-1}$ soil) was recorded in $\mathrm{T}_{5}$ treatment while the lowest exchangeable potassium $\left(0.15 \mathrm{cmol} \mathrm{kg}^{-1}\right.$ soil) was recorded in $T_{1}$ treatment (Table 3). Wang et al. (2014) indicated that the amounts of the extractable $\mathrm{K}$ increased by biochar addition and they found that the $\mathrm{K}$ content of soil increased from 0.11 to $0.83 \mathrm{cmol} \mathrm{kg}^{-1}$ soil.

Application of different level of biochar significantly influenced the available Sulphur (ppm) in soil (Table 3). The maximum available Sulphur (26.66 ppm) found from $\mathrm{T}_{5}$ (RFD+Biochar @ $\left.7.5 \mathrm{t} \mathrm{ha}^{-1}\right)$ treatment while the minimum (16.50 ppm) was found from $\mathrm{T}_{1}$ treatment. This result was disagreed by Liard et al., 2010. They found that extractable $S$ decreased with increasing levels of biochar.

\section{Conclusion}

Potato growth, tuber yield and quality of potato significantly increased when biochar was applied in combination with inorganic fertilizers. Application of biochar @ 7.5 t ha $^{-1}$ along with recommended dose of inorganic fertilizer resulted highest tuber yield (35.76 $\left.\mathrm{t} \mathrm{ha}^{-1}\right)$ and quality parameters like $\%$ dry matter content (25.33) and specific gravity (1.12).

\section{References}

Akhtar, S.S., Li, G., Andersen, M.N., Liu, F., 2014. Biochar enhances yield and quality of tomato under reduced irrigation. Agricultural Water Management 138, 37- 44.

Aller, D., Mazur, R., Moore, K., Hintz, R., Laird, D., Horton, R., 2017. Biochar age and crop rotation impacts on soil quality. Soil Science Society of America Journal 81(5), 1157-1167.

Al-Wabel, M.I., Hussain, Q., Usman, A.R.A., Ahmad, M., Abdul jabbar, A., Sallam, A.S., 2017. Impact of biochar properties on soil conditions and agricultural sustainability: a review. Land Degradation and Development 29, 2124-2161.

Atkinson, C.J., Fitzgerald, J.D., Hipps, N.A., 2010. Potential mechanisms for achieving agricultural benefits from biochar application to temperate soils: a review. Plant Soil 337, 1-18.

Bhattacharjya, S., Chandra, R., Pareek, N., Raverkar, K.P., 2016. Biochar and crop residue application to soil: effect on soil biochemical properties, nutrient availability and yield of rice (Oryza sativa L.) and wheat (Triticum aestivum L.). Archives of Agronomy and Soil Science 62, 1095-1108.

Biederman, L.A., Harpole, W.S., 2013. Biochar and its effects on plant productivity and cycling: a meta-analysis. G.C.B. Bioenergy, 202-214.

Bonanomi, G., Ippolito, F., Cesarano, G., Nanni, B., Lombardi, N., Rita, A., Scala, F., 2017. Biochar as plant growth promoter: better off alone or mixed with organic amendments?. Frontiers in Plant Science 8, 1570.

Brassard, P., Godbout, S., Raghavan, V., 2016. Soil biochar amendment as a climate change mitigation tool: key parameters and mechanisms involved. Journal of
Environmental Management 181, 484-497.

Carter, S., Shackley, S., Sohi, S., BounSuy, T., Haefele, S., 2013. The impact of biochar application on soil properties and plant growth of pot grown lettuce (Lactuca sativa) and Cabbage (Brassica chinensis). Agronomy 3, 404 - 418.

Chan, K.Y., Van Zwieten, L., Meszaros, I., Downie, A., Joseph, S., 2007. Agronomic values of green waste biochar as a soil amendment. Soil Research 45(8), 629-634.

Deenik, J.L., McClellan, T., Uehara, G., Antal, M.J., Campbell, S., 2010. Charcoal volatile matter content influences plant growth and soil nitrogen transformations. Soil Science Society of America Journal 74, 1259-1270.

Dou, L., Komatsuzaki, M., Nakagawa, M., 2012. Effects of biochar, Mokusakueki and Bokashi application on soil nutrients, yields and qualities of sweet potato. International Research Journal of Agricultural Science and Soil Science 2(8), 318-327.

Elfresh, F., Tekalign T., Solomon, W., 2011. Processing quality of improved potato (Solanum tuberosum L.) cultivars as influenced by growing environment and Blancing. African Journal of Food Science 5(6), 24-332.

El-Metwaly, H.M.B., 2020. Response of potato growth, yield and quality to fulvic acid and biochar applications under different levels of chemical fertilization. Journal of Plant Production 11(2), 145-151.

FAOSTAT (FAO, Statistics Division), 2019. Statistical database. Food and Agricultural Organization of the United Nations, Rome, Italy.

Gaskin, J.W., Speirm R.A., Harris, K., Das, K.C., Lee, R.D., Morris, L.A., Fisher, D.S., 2010. Effect of peanut hull and pine chip biochar on soil nutrients, corn nutrient status, and yield. Agronomy journal 102, 623-633.

Gomez, K.A., Gomez, A.A., 1984. Statistical Procedure for Agricultural Research (2 ${ }^{\text {nd }}$ Edn.), International Rice Research Institute, A Wiley-Interscience Publication 28-192.

Graber, E.R., Harel, Y.M., Kolton, M., Cytryn, E., Silber, A., David, D.R., Elad, Y., 2010. Biochar impact on development and productivity of pepper and tomato grown in fertigated soilless media. Plant Soil 337(1-2), 481-496.

Gul, S., Whalen, J.K., Thomas, B.W., Sachdeva, V., Deng, H.Y., 2015. Physicochemical properties and microbial responses in biochar-amended soils: mechanisms and future directions. Agricultural Ecosystem and Environment 206, 46-59.

Gupta, R.K., Hussain, A., Sooch, S.S., Kang, J.S., Sharma, S., Dheri, G.S., 2020. Rice straw biochar improves soil fertility, growth and yield of rice-wheat system on a sandy loam soil. Experimental Agriculture 56(1), 118-131.

Hollister, C.C., Bisogni, J.J., Lehmann, J., 2013. Ammonium, nitrate, and phosphate sorption to and solute leaching from biochars prepared from corn stover (Zea mays L.) and oak wood (Quercus spp.). Journal of Environmental 
Quality 42, 137-144.

Jeffery, S., Bezemer, T.M., Cornelissen G., Kuyper, T.W., Lehmann, J., Mommer, L., Sohi, S.P., van de Voorde, T.F.J., Wardle, D.A., Van Groenigen, J.W., 2014. The way forward in biochar research: targeting trade-offs between the potential wins. GCB Bioenergy (in press).

Koide, R.T., 2017. Biochar-Arbuscular mycorrhiza interaction in temperate. Soils. In Mycorrhizal Mediation of Soil, 461-477.

Laird, D.A., Fleming, P., Davis, D.D., Horton, R., Wang, B.Q., Karlen, D.L., 2010. Impact of biochar amendments on the quality of a typical Midwestern agricultural soil. Geoderma 158(3-4), 443-449.

Lal, R., 2009. Soil degradation as a reason for inadequate human nutrition. Food Security 1, 45-57.

Lehmann, J., 2007. A handful of carbon', Nature 447(7141), 1434.

Liang, Z., Chen, S., Yang, Y., Zhou, Y., Shi, Z., 2019. Highresolution three-dimensional mapping of soil organic carbon in China: Effects of soil grids products on national modeling. Science of the Total Environment 685, 480-489.

Mizuta, K., Matsumoto, T., Hatate, Y., Nishihara, K., Nakanishi, T., 2004. Removal of nitrate nitrogen from drinking water using bamboo powder charcoal. Bio-resource Technology 95(3), 255-257.

Mohammed, W., 2016. Specific gravity, dry matter content, and starch content of potato (Solanum tuberosum L.) varieties cultivated in Eastern Ethiopia. East African Journal of Sciences 10(2), 87-102.

Nair, A., Kruse, R.A., Tillman, J.L., Lawson, V., 2014. Biochar application in potato production. lowa State Res. Farm Progress Rep., 2027. (http:// lib.dr.iastate.edu/farms reports/2027; Last accessed Dec. $16^{\text {th }}$ 2017).

Nair, A., Lawson, V., 2015. Application of biochar in potato production and its effects on soil properties, crop yield and quality. American Society Horticultural Science 50(9), 151-152.

Olsen, S.R., Cole, C.V., Watanable, F.S., Dean, L.A., 1954. Estimation of available phosphorus in soils by extraction with sodium bicarbonate, U.S. Department of Agriculture, Circular, 939.

Page, A.L., Miller, R.H., Keeney, D.R., 1982. Methods of analysis part 2, chemical and microbiological properties 2nd Ed. Soil science socity of American Inc. Madson, Wisconsion, USA, 403-430.

Peng, X., Ye, L.L., Wang, C.H., Zhou, H., Sun, B., 2011. Temperature and duration dependent rice straw-derived biochar: characteristics and its effects on soil properties of an ultisol in southern China. Soil Tillage Research 112(2), 159-166.

Rawat, J., Saxena, J., Sanwal, P., 2019. Biochar: a sustainable approach for improving plant growth and soil properties. In Biochar-An Imperative Amendment for Soil and the Environment. Intech-Open.
Schulz, H., Glaser, B., 2012. Effects of biochar compared to organic and inorganic fertilizers on soil quality and plant growth in a greenhouse experiment. Journal of Soil Science and Plant Nutrition 175, 410-422.

Schulz, H., Glaser, B., 2012. Effects of biochar compared to organic and inorganic fertilizers on soil quality and plant growth in a greenhouse experiment. Journal of Plant Nutrition and Soil Science 175, 410-422.

Silva, I.C., Fernandes L.A., Sampaio, C.R., 2017. Growth and production of common bean fertilized with biochar. Ciencia Rural 47(11), 1-8.

Sohi, S.P., Krull, E., Lopez-Capel, E., Bol, R., 2010. A review of biochar and its use and function in soil. Advances in Agronomy 105, 47-82.

Vaccari, F.P., Maienza, A., Miglietta, F., Baronti, S., Lonardo, S.D., Giagnoni L., Lagomarsino, A., Pozzi, A., Pusceddu, E., Ranieri, R., Valboa, G., Genesio L., 2015. Biochar stimulates plant growth but not fruit yield of processing tomato in a fertile soil. Agriculture, Ecosystems and Environment 207, 163-170.

Van Zwieten, L., Kammann, C., Cayuela, M.L., Singh, B.P., Joseph, S., Kimber, S., Spokas, K., 2015. Biochar effects on nitrous oxide and methane emissions from soil. Biochar for environmental management: science and technology. $2^{\text {nd }}$ ed. London, New York: Earthscan Books Ltd, 489-520.

Van Zwieten, L., Kimber, S., Morris, S., Chan, K.Y., Downie, A., Rust, J., Joseph, S., Cowie, A., 2010. Effects of biochar from slow pyrolysis of paper mill waste on agronomic performance and soil fertility. Plant Soil 327, 235-246.

Wang, Y., Yin, R., Liu, R., 2014. Characterization of biochar from fast pyrolysis and its effect on chemical properties of the tea garden soil. Journal of Analytical and Applied Pyrolysis 110, 375-381.

Xu, G., Sun, J., Shao, H., Chang, S.X., 2014. Biochar had effects on phosphorus sorption and desorption in three soils with differing acidity. Ecological Engineering 62, 54-60.

Youseef, M.E.A., Al-Easily, I.A.S., Nawar, D.A.S., 2017. Impact of biochar addition on productivity and tubers quality of some potato cultivars under sandy soil conditions. Egyptian Journal of Horticulture 44(2), 199-217.

Zhang, A., Bian, R., Pan, G., Cui, L., Hussain, Q., Li, L., Zheng, J., Zhang, X., Han, X., Yu, X., 2012. Effects of biochar amendment on soil quality, crop yield and greenhouse gas emission in a Chinese rice paddy: a field study of 2 consecutive rice growing cycles. Field Crops Research 127, 153-160.

Zhou, H., Fang, H., Zhang, Q., Wang, Q., Chen, C., Mooney, S. J., $\mathrm{Du}, \mathrm{Z}$., 2019. Biochar enhances soil hydraulic function but not soil aggregation in a sandy loam. European Journal of Soil Science 70(2), 291-300. 